Article

\title{
Eleven Monovarietal Extra Virgin Olive Oils from Olives Grown and Processed under the Same Conditions: Effect of the Cultivar on the Chemical Composition and Sensory Traits
}

\author{
Giuseppe Di Lecce ${ }^{1}$, Maria Piochi ${ }^{2}$, Deborah Pacetti ${ }^{3, *}$, Natale G. Frega ${ }^{3}$, Edoardo Bartolucci ${ }^{3}$, \\ Serena Scortichini ${ }^{4}$ and Dennis Fiorini ${ }^{4}$ \\ 1 Independent Researcher, Expert in Food Science and Technology, 26100 Cremona, Italy; \\ leccegius1980@gmail.com \\ 2 University of Gastronomic Sciences, Piazza Vittorio Emanuele 9, 12042 Pollenzo, Italy; m.piochi@unisg.it \\ 3 Department of Agricultural, Food, and Environmental Sciences, Polytechnic University of Marche, \\ Via Brecce Bianche, I-60131 Ancona, Italy; n.g.frega@univpm.it (N.G.F.); e.bartolucci@pm.univpm.it (E.B.) \\ 4 School of Science and Technology, Chemistry Division, University of Camerino, V.S. Agostino 1, \\ I-62032 Camerino, Italy; serena.scortichini@unicam.it (S.S.); dennis.fiorini@unicam.it (D.F.) \\ * Correspondence: d.pacetti@univpm.it; Tel.: +39-07-1220-4307
}

Received: 19 June 2020; Accepted: 6 July 2020; Published: 9 July 2020

\begin{abstract}
Eleven Italian monovarietal extra virgin olive oils (MEVOOs) (Carboncella, Coratina, Frantoio, Leccino, Marzio, Maurino, Moraiolo, Piantone di Falerone, Pendolino, Rosciola, Sargano di Fermo) from olives grown in the same experimental olive orchard, under the same conditions (fertilization, irrigation), and processed with the same technology (three-way continuous plant) were investigated. As a result, the impact of the olive cultivar on fatty acid and triacylglycerols composition, oxidative stability, polar phenolic profile and sensory properties (panel test) of the oil was assessed. Pendolino, Maurino and Marzio oils presented the highest levels $(p<0.01)$ of palmitic, linoleic and linolenic acids \% and the lowest oleic:linoleic ratio. Within triacylglycerols, triolein (OOO) strongly varied among the oils, with Coratina and Leccino having the highest content. Frantoio showed the lowest 1-Stearoyl-2-palmitoyl-3-oleylglycerol and 1,3-Distearoyl-2-oleylglycerol amounts. Rosciola showed the highest level $(p<0.01)$ for two of the most abundant secoiridoid derivatives (the dialdehydic forms of decarboxymethyl elenolic acid linked to hydroxytyrosol and tyrosol). A good correlation was found between total phenolic content and oxidative stability, indicating Marzio and Leccino respectively as the richest and poorest genotypes. Sensory variability among varieties was mainly linked to perceived bitterness, pungency and fruitiness, while no effects were found on secondary flavors.
\end{abstract}

Keywords: monocultivar; autochthonous; cultivar; sensory properties; phenolic substances; triacylglycerols

\section{Introduction}

Olive oil markets are changing rapidly. Monovarietal extra virgin olive oil (MEVOOs) are gaining increasing interest allowing for further segmenting of the market and creating new trends in high market niches [1,2].

MEVOOs are defined as oils obtained by the transformation of olives from one variety. Traditionally, EVOOs are made of blends of all the olive varieties present on each farm but more recently, milling technology and machinery allow for separate milling of even small quantities of olives [3]. 
In 2017/2018, Italy was the second largest European olive oil producer after Spain [4] and it is currently the leading country for cultivar biodiversity, accounting for over 800 varieties [5]. Since MEVOOs are products reflecting the characteristics of a country beyond genetics, their systematic sensory and chemical characterization has a pivotal role in order to identify quality oils with remarkable diversity and clear identity. A detailed description of the chemical and sensory traits of MEVOO produced with olive cultivars among the most widespread in Italy, such as Frantoio, Leccino and Moraiolo was reported by several authors [6-9]. Additionally, the features of MEVOO from cultivars typical of different Italian regions producing appreciated oils were also highlighted [10-16].

However, a frequent limitation in studies on MEVOOs is that cultivars often come from different geographical areas $[14,17,18]$; therefore, other variables like the pedoclimatic characteristics may introduce bias in the characterization. In fact, it is known that the same cultivar grown in different pedoclimatic conditions (altitude, latitude, climatic conditions, soil composition etc.) shows different values in fatty acid composition, phenolic content and oxidative stability [19-21]. Since pedoclimatic aspects, olive ripeness, harvesting time and the extraction system, strongly impact on the chemical composition and sensory properties of oils [22-24], it is recommended to control these factors when studying characteristics of MEVOOs. Within the heritage of Mediterranean diet products, MEVOOs represent precious contributions, whose sensory and healthy properties are explained by chemical compositional peculiarities, in many cases not yet investigated.

Thus, the present study aimed to perform a chemical and sensory characterization of eleven different MEVOOs. Some of the cultivars investigated (Leccino, Frantoio, Maurino, Moraiolo, Pendolino) are well known and widely cultivated in several Italian areas having adequate pedoclimatic conditions, while other cultivars are less diffused and present only in their native regions (Carboncella, Coratina, Marzio, Piantone di Falerone, Rosciola, Sargano di Fermo). Beyond the characterization of MEVOOs from minor cultivars never investigated before, an important outcome of this study is the contribution to understanding the effect that the genetic background of the fruit (effect of cultivar) plays on the chemical composition and sensory properties of the oil. In fact, in the present study all the other parameters are the same for all the cultivars investigated, i.e., olives are grown in the same experimental olive orchard and under the same conditions (fertilization, irrigation) and processed with the same technology.

\section{Materials and Methods}

\subsection{Standard, Reagents and Solvents}

The Folin-Ciocalteu reagent and gallic acid were obtained from Merck \& Co. Inc. (Darmstadt, Germany). The fatty acid methyl esters, triacylglycerols, pyridine, 1,1,1,3,3,3-Hexamethylsiloxane and chloroxilane were purchased from Sigma-Aldrich Inc. (St. Louis MO, USA). The phenols p-Hydroxyphenylethanol ( $p$-HPEA), 3,4-Dihydroxyphenylacetic acid, vanillic acid vanillin, oleuropein, luteolin and apigenin, were purchased from Extrasynthése (Genay, France), Sigma (St. Louis, MO, USA) and Fluka (Buchs, Switzerland). High Pressure Liquid Chromatography (HPLC) grade solvents were purchase from Merck (Darmstadt, Germany). All the solvents and solutions were filtered through a $0.45 \mu \mathrm{m}$ politetrafluoroetilene filter (PTFE, Supelco, Bellefonte, PA, USA).

\subsection{Olive Oil Samples}

MEVOOs obtained from eleven Italian cultivars were studied. Olive fruits, collected in the crop year 2018/2019, were all provided from the experimental farm "Pasquale Rosati" of the Polytechnic University (Ancona, Italy), where the olive trees were cultivated under identical agronomic and pedoclimatic conditions. However, some of the varieties investigated are currently cultivated on national scale (Leccino, Frantoio, Maurino, Moraiolo, Pendolino), while others are autochthonous of three Italian regions: Marche (Carboncella, Piantone di Falerone, Rosciola, Sargano di Fermo), Tuscany (Marzio) and Apulia (Coratina). 
The healthy fruits were harvested by handpicking at the same maturity index (values around 3.5, based on the color and texture of the olive drupe according to the Jaen index [25]: 100 olive fruits were classified into eight different groups and the index was calculated as $\Sigma\left(A_{i} n_{i}\right) / 100$, where $A$ is the group number and $\mathrm{n}$ is the number of fruits in the group). After harvesting, the olive fruits were processed by continuous system technology. For each cultivar, approximately $350-400 \mathrm{~kg}$ of olives were collected, and each batch was processed in a three-way continuous plant (P. Barigelli \& C., Cingoli, Italy). The olive fruits were defoliated and washed prior to crushing, and then processed by hammer crusher and malaxer. The temperature of the pulp in the malaxer was set at $26^{\circ} \mathrm{C}$. The olive oil was separated by B/D 400 decanter (P. Barigelli \& C., Cingoli, Italy) and poured into green sealed glass bottles $(0.25 \mathrm{~mL}$ each) and the headspace was approximately $10 \mathrm{~mL}$. The EVOO bottles were stored in the dark and at room temperature $\left(20^{\circ} \mathrm{C} \pm 1{ }^{\circ} \mathrm{C}\right)$ and were opened after five months for the analysis. Each analysis was performed in triplicate.

\subsection{Determination of Legal Quality Parameters}

The free acidity (FA, g oleic acid in $100 \mathrm{~g}$ of oil), peroxide value (PV, $\mathrm{mg} \mathrm{eq} \mathrm{O}_{2} \mathrm{~kg}^{-1}$ of oil) and UV spectrophotometric determinations were carried out for each oil sample according to the EEC Reg. no. $2568 / 1991$ and subsequent modifications. Spectrophotometric determinations $K_{232}, K_{270}$ and $\Delta K$ were carried out using an ultraviolet, visible light and near infrared spectrophotometer (UV-Vis-Nir Cary5000, Varian, Leiní, Italy).

\subsection{Sensory Evaluation according to the Panel Test}

The sensory evaluation was performed by a trained panel (O.L.E.A. Organizzazione Laboratorio Esperti Assaggiatori, Pesaro, Italy) accredited by the Ministry of Agricultural, Food and Forestry Policies (MIPAAF) and according to the procedure reported in the EEC Reg. no. 2568/1991 and in its subsequent modifications. Panelists used a profile sheet adapted from the International Olive Council (IOC) method for designation of origin [26]. The vocabulary included 12 positive attributes: nine descriptors for volatile sensations perceived by retro-olfaction (fruity, greenly fruity, ripely fruity, olive leaf, grass, artichoke, tomato, almond, apple), two tastes (bitter, sweet) and one kinesthetic sensation (pungency). Trained assessors could also mark defects if perceived. Samples (15 mL) were served in standard glass [27] and codified with random three-digit codes. Samples were assessed in three evaluation sessions and served in balanced and randomized order across panelists.

\subsection{Determination of Fatty Acid Composition}

To determine fatty acid composition, fatty acid methyl esters (FAMEs) were obtained with $1 \mathrm{M} \mathrm{KOH}$ in methanol [28], and analyzed using a gas chromatograph (GC) HRGC Mega 2 series Model MFC 800 (Fisons Instruments, Milan, Italy). The GC instrument was equipped with a flame ionization detector (FID) and a fused silica capillary column coated with $80 \%$ biscyanopropyl $/ 20 \%$ cyanopropylphenyl polysiloxane (SP 2330, $60 \mathrm{~m}$ length $\times 0.25 \mathrm{~mm}$ i.d. $0.2 \mathrm{~m}$ film thickness, Supelco, St. Louis, MO, USA). The carrier gas was helium $\left(2 \mathrm{~mL} \mathrm{~min}^{-1}\right)$; the splitting ratio was 1:80. The injector and detector temperatures were set at $250{ }^{\circ} \mathrm{C}$; the temperature program started at $150{ }^{\circ} \mathrm{C}$ and was raised to $220^{\circ} \mathrm{C}$ at a rate of $3{ }^{\circ} \mathrm{C} \mathrm{min}-1$ and was held for $30 \mathrm{~min}$. The FAMEs were identified by comparison with known standards.

\subsection{Triacylglycerol Determination}

A $1 \mathrm{~g}$ aliquot of oil was added with internal standard solution (triundecanoin, $1 \mathrm{mg} / \mathrm{mL}$ ) was silylated according to Sweeley et al. [29] and injected into a GC-FID (HRGC Model 5300, Carlo Erba, Milan, Italy) equipped with a fused-silica capillary column coated with a $50 \%$ phenyl $-/ 50 \%$ methylpolysiloxane (CP-TAP, $60 \mathrm{~m} \times 25 \mathrm{~mm} \times 0.25 \mathrm{~mm}$ i.d., film thickness $0.1 \mathrm{~mm}$, Varian Walnut Creek, CA, USA). The chromatographic method was set according to Boselli et al. [30]. Peak identification was carried out by comparison of the relative retention time with those reported in the literature and with 
the retention times of the standard substances [31]. Quantitative analyses were performed adopting the corrected area normalization method (with triundecanoin as internal standard).

\subsection{Determination of the Oxidative Stability}

The oxidative stability of the oils was determined by Rancimat apparatus (Metrohm model 679, Herisau, Switzerland), measuring the induction time in response to forced oxidation (induction period) of $5 \mathrm{~g}$ sample heated at $110{ }^{\circ} \mathrm{C}$ under an air flow of $20 \mathrm{~L} \mathrm{~h}^{-1}$. The induction period (expressed in hours) was determined by drawing the two tangents of the time-conductivity curve and projecting the intersection onto the time-axis.

\subsection{Phenols Determinations by Folin-Ciocalteu Assay and High-Performance Liquid Chromatography (HPLC) Coupled with Diode Array Detector (DAD)}

Phenolic compounds were extracted three times following the procedure described by Boselli et al. [32]. The phenols extracted for Folin-Ciocalteu assay were resuspended in $1 \mathrm{~mL}$ methanol and the total phenol content was determined at $765 \mathrm{~nm}$ according Singleton et al. [33]. The results were expressed as gallic acid equivalents $\left(\mathrm{mg} \mathrm{kg}^{-1}\right.$ oil) based on a calibration curve $\left(R^{2}=0.993\right)$. Phenols were also quantified by HPLC coupled with a diode array detector (DAD) and a 3,4-Dihydroxyphenylacetic acid solution was used as internal standard. After the extraction procedure, the dry extracts were resuspended in $1 \mathrm{~mL}$ methanol and the solutions were filtered through $0.2 \mathrm{~mm}$ regenerated cellulose filters (Schleicher \& Schuell, Dassel, Germany). Phenolic compounds were separated by Chromspher C18 (5 $\frac{1}{4} \mathrm{~m}$ particle size, $25 \mathrm{~cm} \times 4.6 \mathrm{~mm}$ i.d. column, Chrompack Middelburg, Netherlands), using a Varian 9010 ternary pump (Walnut Creek, CA, USA). The sample was injected into a $20 \mathrm{~mL}$ loop and the mobile phase flow rate was $0.7 \mathrm{~mL} \mathrm{~min}{ }^{-1}$. The gradient elution was carried out according to Fiori et al. [34]. A Varian Prostar PDA 330 was used as detector to acquire phenolic acids, phenyl ethyl alcohols and secoiridoids at $280 \mathrm{~nm}$, while flavones were detected at $350 \mathrm{~nm}$. The data were acquired using Varian Star 6.3 software. Using their respective standards $\left(R^{2}=0.998,0.999,0.996\right.$ and 0.998), 3,4-dihydroxyphenylethanol (3,4-DHPEA), $p$-hydroxyphenylethanol ( $p$-HPEA), vanillic acid and vanillin, respectively, were quantified. Secoiridoids were quantified with oleuropein $\left(R^{2}=0.999\right)$, while luteolin and apigenin were quantified with their standard $\left(R^{2}=0.998, R^{2}=0.996\right.$, respectively). For structural elucidation, the HPLC system was coupled online to an LCQ ion-trap mass spectrometer (Thermoquest, San José, CA, USA) as reported by Boselli et al. [32].

\subsection{Data Analysis}

Oils were firstly classified as extra virgin olive oils by official methods [26]; for all attributes the robust coefficient of variation (\%) was lower than $20 \%$. To allow a statistical comparison across the cultivars for the perceived intensity of sensory attributes, two-way ANOVA models were conducted separately on intensity values given to each sensory attribute from panel descriptive data (fixed factors: cultivar, assessors). This statistical approach, that can be exploited when the aim is the valorization and differentiation of oils [35,36] (like in the present case), allows the estimation of the effect of the cultivar on the perceived intensity of the sensations expressed by the F Fisher's ratio, followed by Tukey's pairwise test conducted on the mean values $(p<0.05)$. Correlations among variables were tested with the Pearson coefficient $(R)(p<0.05)$. A principal component analysis (PCA) was conducted on significant chemical and sensory variables, to exploratorily study the relationships among variables and cultivars. Analyses were conducted with XLStat 2019.1.1, Addinsoft, Boston, MA, USA.

\section{Results and Discussion}

\subsection{Legal Quality Parameters}

Table 1 shows that, considering the parameters FA, $P V, K_{232}, K_{270}$ and $\Delta K$, all MEVOOs samples complied with limits required for extra virgin olive oil categorization [37]. FA ranged from 0.22 to 
$0.39 \%$ (g oleic acid per $100 \mathrm{~g}$ of oil), much lower than $0.8 \%$ set for EVOOs, denoting a good quality and healthy status of olives, which were immediately transformed after harvesting. PV and UV spectrophotometric indices are the two main parameters indicating the oil rancidity progress state. Values for the peroxide and UV indices were lower than the legal limits $\left(\mathrm{PV}<20\right.$ meq $\mathrm{O}_{2}$ per $\mathrm{kg}$ of oil -meq $\mathrm{O}_{2} \mathrm{~kg}^{-1}-; \mathrm{K}_{232}<2.5, \mathrm{~K}_{270}<0.22$ and $\Delta \mathrm{K}<0.01$ ). The low $\mathrm{PV}$ levels ranged between 4.0 and 7.2 meq $\mathrm{O}_{2} \mathrm{~kg}^{-1}$, while UV indices did not show significant differences across the samples.

Table 1. Olive oil quality parameters of the eleven monovarietal oils investigated.

\begin{tabular}{cccccc}
\hline Cultivar & Free Acidity & Peroxide Value $^{\mathbf{Z}}$ & $\mathbf{K}_{\mathbf{2 3 2}}$ & $\mathbf{K}_{270}$ & $\Delta \mathbf{K}$ \\
\hline Carboncella & $0.33^{\mathrm{abcd}} \pm 0.03$ & $5.10^{\mathrm{d}} \pm 0.07$ & $1.73^{\mathrm{a}} \pm 0.13$ & $0.12^{\mathrm{a}} \pm 0.002$ & $0.003^{\mathrm{a}} \pm 0.001$ \\
Coratina & $0.34^{\mathrm{abc}} \pm 0.02$ & $6.20^{\mathrm{bc}} \pm 0.14$ & $1.63^{\mathrm{a}} \pm 0.12$ & $0.13^{\mathrm{a}} \pm 0.003$ & $0.002^{\mathrm{a}} \pm 0.001$ \\
Frantoio & $0.23^{\mathrm{defg}} \pm 0.01$ & $6.27^{\mathrm{b}} \pm 0.10$ & $1.59^{\mathrm{a}} \pm 0.11$ & $0.10^{\mathrm{a}} \pm 0.002$ & $0.003^{\mathrm{a}} \pm 0.001$ \\
Leccino & $0.32^{\mathrm{bcde}} \pm 0.03$ & $7.15^{\mathrm{a}} \pm 0.07$ & $1.83^{\mathrm{a}} \pm 0.19$ & $0.15^{\mathrm{a}} \pm 0.005$ & $0.002^{\mathrm{a}} \pm 0.001$ \\
Marzio & $0.25^{\mathrm{g}} \pm 0.02$ & $5.96^{\mathrm{bc}} \pm 0.08$ & $1.86^{\mathrm{a}} \pm 0.16$ & $0.14^{\mathrm{a}} \pm 0.004$ & $0.005^{\mathrm{a}} \pm 0.001$ \\
Maurino & $0.28^{\mathrm{cdef}} \pm 0.01$ & $5.05^{\mathrm{d}} \pm 0.07$ & $1.77^{\mathrm{a}} \pm 0.11$ & $0.16^{\mathrm{a}} \pm 0.006$ & $0.003^{\mathrm{a}} \pm 0.001$ \\
Moraiolo & $0.21^{\mathrm{fg}} \pm 0.01$ & $4.12^{\mathrm{a}} \pm 0.16$ & $1.65^{\mathrm{a}} \pm 0.19$ & $0.13^{\mathrm{a}} \pm 0.004$ & $0.003^{\mathrm{a}} \pm 0.001$ \\
Piantone di Falerone & $0.39^{\mathrm{a}} \pm 0.04$ & $6.80^{\mathrm{a}} \pm 0.15$ & $1.73^{\mathrm{a}} \pm 0.24$ & $0.11^{\mathrm{a}} \pm 0.002$ & $0.003^{\mathrm{a}} \pm 0.001$ \\
Pendolino & $0.22^{\text {efg }} \pm 0.02$ & $6.85^{\mathrm{a}} \pm 0.10$ & $1.76^{\mathrm{a}} \pm 0.18$ & $0.15^{\mathrm{a}} \pm 0.003$ & $0.004^{\mathrm{a}} \pm 0.001$ \\
Rosciola & $0.38^{\mathrm{ab}} \pm 0.04$ & $5.90^{\mathrm{c}} \pm 0.12$ & $1.76^{\mathrm{a}} \pm 0.17$ & $0.13^{\mathrm{a}} \pm 0.004$ & $0.002^{\mathrm{a}} \pm 0.001$ \\
Sargano di Fermo & $0.28^{\text {cdef }} \pm 0.02$ & $6.85^{\mathrm{a}} \pm 0.08$ & $1.64^{\mathrm{a}} \pm 0.21$ & $0.10^{\mathrm{a}} \pm 0.001$ & $0.002^{\mathrm{a}} \pm 0.001$ \\
\hline
\end{tabular}

Results are expressed as mean \pm standard deviation $(n=3) ;{ }^{\mathrm{x}} \mathrm{g}$ oleic acid in $100 \mathrm{~g}$ of oil; ${ }^{\mathrm{z}} \mathrm{mg} \mathrm{eq} \mathrm{O}_{2} \mathrm{~kg}^{-1}$ of oil; $\mathrm{K}_{232}$, $\mathrm{K}_{270}$ : UV absorption at $K=232$ and $270 \mathrm{~nm}$; different letters in the same column indicate significantly different values $(p<0.001)$.

\subsection{Sensory Evaluation According to the Panel Test}

As expected from the optimal quality of olive fruits and the technological practices, no sensory defect was detected. From two-way ANOVA models on the intensity of positive attributes (Table 2), five attributes significantly differed across oils from different varieties, as indicated by the significant Fisher's $\mathrm{F}$ ratio from ANOVA models: fruity $(\mathrm{F}=2.1, p<0.03)$, greenly fruity $(\mathrm{F}=2.39, p<0.01)$, bitter $(\mathrm{F}=4.89, p<0.001)$, sweet $(\mathrm{F}=5.52, p<0.001)$ and pungency $(\mathrm{F}=4.14, p<0.001)$. Secondary descriptors (olive leaf, grass, artichoke, tomato, almond, apple, ripely fruity) were occasionally perceived but at low intensities $(\leq 2.5)$ and without significant differences $(p>0.05)$ among the oils. The lack of significant differences across varieties did not allow a clear diversification, probably due to the low intensity values of these secondary descriptors. Other reports similarly showed that secondary notes differ slightly across cultivars $[5,38]$ as compared to major attributes, e.g., bitterness and pungency, and they are perceived at modest/low intensities.

Table 2. Sensory evaluation and perceived intensity (expressed as means of ratings given by assessors \pm standard error of the means) of the main sensory attributes in the investigated monovarietal oils.

\begin{tabular}{|c|c|c|c|c|c|}
\hline Cultivar & Fruity & Bitter & Pungency & Greenly Fruity & Sweet \\
\hline Carboncella & $2.6^{\mathrm{ab}} \pm 0.2$ & $3.0^{\mathrm{abc}} \pm 0.3$ & $2.9^{b c} \pm 0.2$ & $1.7^{\mathrm{b}} \pm 0.4$ & $2.4^{c} \pm 0.3$ \\
\hline Coratina & $3.1^{\mathrm{ab}} \pm 0.2$ & $3.6^{\mathrm{ab}} \pm 0.3$ & $3.1^{\mathrm{abc}} \pm 0.2$ & $1.9^{\mathrm{ab}} \pm 0.4$ & $2.7^{b c} \pm 0.3$ \\
\hline Frantoio & $2.9^{\mathrm{ab}} \pm 0.2$ & $1.9^{c} \pm 0.3$ & $3.1^{\mathrm{abc}} \pm 0.2$ & $2.0^{\mathrm{ab}} \pm 0.4$ & $4.0^{\mathrm{ab}} \pm 0.3$ \\
\hline Leccino & $2.5^{b} \pm 0.2$ & $1.9^{c} \pm 0.3$ & $2.1^{\mathrm{c}} \pm 0.2$ & $1.8^{\mathrm{ab}} \pm 0.4$ & $4.5^{\mathrm{a}} \pm 0.3$ \\
\hline Marzio & $3.5^{\mathrm{a}} \pm 0.2$ & $4.1^{\mathrm{a}} \pm 0.3$ & $4.1^{\mathrm{a}} \pm 0.2$ & $3.2^{\mathrm{ab}} \pm 0.4$ & $2.3^{c} \pm 0.3$ \\
\hline Maurino & $3.1^{\mathrm{ab}} \pm 0.2$ & $2.3^{b c} \pm 0.3$ & $3.2^{\mathrm{abc}} \pm 0.2$ & $2.2^{\mathrm{ab}} \pm 0.4$ & $3.5^{\mathrm{abc}} \pm 0.3$ \\
\hline Moraiolo & $3.3^{\mathrm{ab}} \pm 0.2$ & $3.0^{\mathrm{abc}} \pm 0.3$ & $3.1^{\mathrm{abc}} \pm 0.2$ & $3.8^{\mathrm{a}} \pm 0.4$ & $3.4^{\mathrm{abc}} \pm 0.3$ \\
\hline Piantone di Falerone & $3.3^{\mathrm{ab}} \pm 0.2$ & $3.0^{\mathrm{abc}} \pm 0.3$ & $3.2^{\mathrm{abc}} \pm 0.2$ & $2.5^{\mathrm{ab}} \pm 0.4$ & $2.9^{b c} \pm 0.3$ \\
\hline Pendolino & $3.1^{\mathrm{ab}} \pm 0.2$ & $2.7^{b c} \pm 0.3$ & $3.1^{\mathrm{abc}} \pm 0.2$ & $2.5^{\mathrm{ab}} \pm 0.4$ & $2.9^{b c} \pm 0.3$ \\
\hline Rosciola & $2.9^{\mathrm{ab}} \pm 0.2$ & $3.2^{\mathrm{abc}} \pm 0.3$ & $3.5^{\mathrm{ab}} \pm 0.2$ & $2.8^{\mathrm{ab}} \pm 0.4$ & $2.7^{b c} \pm 0.3$ \\
\hline Sargano di Fermo & $3.2^{\mathrm{ab}} \pm 0.2$ & $3.0^{\mathrm{abc}} \pm 0.3$ & $3.6^{\mathrm{ab}} \pm 0.2$ & $3.2^{\mathrm{ab}} \pm 0.4$ & $3.8^{a b} \pm 0.3$ \\
\hline
\end{tabular}

Different letters in the same column indicate significantly different values: fruity $(p<0.03)$, greenly fruity $(p<0.01)$, bitter $(p<0.001)$, sweet $(p<0.001)$ and pungency $(p<0.001)$ obtained from two-way ANOVA models (fixed factors: cultivar, assessors), followed by Tukey's pairwise test $(p<0.05)$. 
As an example, Cantini et al. [38] reported a maximum intensity of 3.0 for secondary notes such as artichoke or almond in 57 cultivars investigated. Instead, bitter, pungency and greenly fruity seemed more related to the cultivar and less linked to agronomical and pedoclimatic influences [39].

Marzio MEVOO was characterized by the significantly highest greenly fruity, bitterness and pungency. Moraiolo was also characterized by a high fruity and greenly fruity (the highest), with a pronounced pungency and bitterness balanced by the sweetness. Leccino was the sweetest, and had the significantly lowest greenly fruity, bitterness and pungency intensities. These results are in agreement with previous reports, describing Coratina as significantly more bitter than Leccino [5]. Sensory similarities were found with some attributes that did not significantly differ across cultivars, such as the intensity of pungency, similar in Marzio, Sargano di Fermo, Rosciola, Piantone di Falerone, Maurino, Frantoio, Moraiolo and Pendolino and bitterness, at the same intensity in Marzio, Coratina, Rosciola, Pendolino, Moraiolo, Carboncella and Sargano di Fermo.

\subsection{Fatty Acid Composition}

The composition of the principal fatty acids of MEVOOs is shown in Table 3. In all the MEVOOs, fatty acids percentages were compliant with the legal limits imposed by EEC Reg. no. 2568, 1991. Moreover, the investigated samples showed fatty acid compositions that are well in the average value ranges reported in literature for various Italian monovarietal oils [11,12,40].

On the whole, our findings corroborated the hypothesis that the oil fatty acid profile is strongly under genetic control. Ben Ayed et al. [41] noticed that oleic acid amounts in olive oil can be strongly related to the polymorphisms of fatty acid-related genes, such as the stearoyl-acyl carrier protein desaturase gene (SAD). TT-SAD.1 genotype was found to be associated with a higher proportion of monounsaturated fatty acids, mainly oleic acid, as well as with lower proportions of palmitic acid, thus causing olive varieties with this genotype to produce more monounsaturated fatty acids, namely oleic acid, than saturated fatty acids.

Indeed, we found clear differences among the MEVOO's fatty acid compositions, mainly in terms of palmitic, oleic, linoleic and linolenic acid contents. Since the investigated oils were obtained with olives cultivated in the same growing conditions and were processed with the same operative conditions, the highlighted differences were related to the olive cultivar.

In detail, the oleic acid content, ranging from 71.55 to $78.42 \%$, clustered the oils into two groups: the first composed of eight varieties (Coratina, Rosciola, Sargano di Fermo, Frantoio, Carboncella, Moraiolo, Leccino, Piantone di Falerone), with the significantly highest values $(p<0.001)$, ranging from 76.2 to $78.4 \%$, and the second with Pendolino, Maurino and Marzio oils, with the lowest values (72.0-73.0\%). Simultaneously, Pendolino, Maurino and Marzio MEVOOs presented the significantly highest levels of palmitic, linoleic and linolenic acids. Thus, Pendolino, Maurino and Marzio oils stood out from the rest for their unfavorable oxidative stability parameters, such as the highest unsaturation index and lowest oleic:linoleic ratio. It is important to notice that high unsaturation index, low percent content of oleic acid and high percent content of linoleic acid bound in the acylglycerol backbone, make olive oil weakly resistant toward oxidation.

Our findings were in line with previous studies reporting the comparison of fatty acid composition in some of the MEVOOs investigated by us, e.g., Bianchi et al. [36] studied the fatty acid profile of Frantoio, Coratina and Moraiolo oils from olives harvested in different Italian regions (i.e., Apulia, Tuscany) revealing that these oils were similar on the basis of oleic acid content. Blasi et al. [6] did not underline significant differences, in terms of overall fatty acids composition, among Frantoio, Leccino and Moraiolo MEVOOs purchased from producers located in central Italy regions. 
Table 3. Fatty acid composition, oleic acid:linoleic acid ratio, insaturation index and triacylglycerols composition of the eleven monovarietal extra virgin olive oils investigated.

\begin{tabular}{|c|c|c|c|c|c|c|c|c|c|c|c|}
\hline Compounds & Carboncella & Coratina & Frantoio & Leccino & Marzio & Maurino & Moraiolo & $\begin{array}{l}\text { Piantone di } \\
\text { Falerone }\end{array}$ & Pendolino & Rosciola & $\begin{array}{c}\text { Sargano di } \\
\text { Fermo }\end{array}$ \\
\hline \multicolumn{12}{|c|}{ Fatty acids (\%) } \\
\hline Palmitic acid & $13.1^{c} \pm 0.6$ & $13.6^{c} \pm 0.6$ & $13.4^{c} \pm 0.7$ & $13.7^{b c} \pm 0.7$ & $14.6^{\mathrm{a}} \pm 0.4$ & $15.1^{\mathrm{a}} \pm 0.8$ & $13.5^{b c} \pm 0.5$ & $13.9^{b c} \pm 0.5$ & $15.3^{\mathrm{a}} \pm 0.8$ & $12.9^{c} \pm 0.8$ & $13.3^{b c} \pm 0.8$ \\
\hline Palmitoleic acid & $0.98^{b} \pm 0.1$ & $1.17^{\mathrm{a}} \pm 0.3$ & $1.08^{\mathrm{a}} \pm 0.2$ & $1.26^{\mathrm{a}} \pm 0.2$ & $0.81^{\mathrm{b}} \pm 0.1$ & $1.26^{\mathrm{a}} \pm 0.1$ & $0.94^{b} \pm 0.1$ & $1.12^{\mathrm{a}} \pm 0.1$ & $1.10^{\mathrm{a}} \pm 0.2$ & $0.97^{b} \pm 0.1$ & $1.04^{\mathrm{ab}} \pm 0.1$ \\
\hline Stearic acid & $1.97^{a} \pm 0.2$ & $1.91^{\mathrm{a}} \pm 0.3$ & $1.83^{b} \pm 0.4$ & $1.69^{b} \pm 0.2$ & $1.92^{a} \pm 0.3$ & $1.68^{b} \pm 0.2$ & $1.89^{a} \pm 0.2$ & $1.94^{\mathrm{a}} \pm 0.1$ & $1.71^{\mathrm{b}} \pm 0.1$ & $2.03^{a} \pm 0.2$ & $1.85^{b} \pm 0.2$ \\
\hline Oleic acid & $77.1^{\mathrm{a}} \pm 4.2$ & $78.8^{\mathrm{a}} \pm 3.9$ & $76.7^{\mathrm{a}} \pm 4.3$ & $76.7^{\mathrm{a}} \pm 4.1$ & $73.0^{\mathrm{bc}} \pm 3.8$ & $72.4^{\mathrm{bc}} \pm 3.5$ & $77.6^{\mathrm{a}} \pm 4.1$ & $75.7^{\mathrm{ab}} \pm 3.7$ & $72.0^{c} \pm 3.8$ & $77.8^{\mathrm{a}} \pm 4.5$ & $76.1^{\mathrm{a}} \pm 4.1$ \\
\hline Linoleic acid & $7.21^{b} \pm 0.7$ & $4.82^{\mathrm{f}} \pm 0.3$ & $6.21^{\mathrm{cd}} \pm 0.5$ & $5.95^{\mathrm{de}} \pm 0.4$ & $8.80^{\mathrm{a}} \pm 0.7$ & $8.72^{\mathrm{a}} \pm 0.6$ & $5.41^{\mathrm{e}} \pm 0.5$ & $6.62^{b c} \pm 0.5$ & $8.95^{\mathrm{a}} \pm 0.6$ & $5.62^{e} \pm 0.4$ & $6.93^{b c} \pm 0.4$ \\
\hline Linolenic acid & $0.62^{c} \pm 0.1$ & $0.64^{c} \pm 0.1$ & $0.71^{\mathrm{c}} \pm 0.1$ & $0.72^{\mathrm{c}} \pm 0.1$ & $0.81^{\mathrm{ab}} \pm 0.1$ & $0.83^{\mathrm{ab}} \pm 0.1$ & $0.70^{\mathrm{c}} \pm 0.2$ & $0.62^{c} \pm 0.1$ & $0.95^{\mathrm{a}} \pm 0.1$ & $0.63^{c} \pm 0.1$ & $0.62^{c} \pm 0.1$ \\
\hline $\begin{array}{c}\text { Oleic } \\
\text { acid/linoleic acid }\end{array}$ & $10.6^{c} \pm 0.8$ & $16.3^{\mathrm{a}} \pm 1.1$ & $12.3^{b c} \pm 0.9$ & $12.9^{b c} \pm 0.8$ & $8.25^{d} \pm 0.5$ & $8.30^{\mathrm{d}} \pm 0.6$ & $14.5^{\mathrm{b}} \pm 1.0$ & $11.4^{b c} \pm 0.9$ & $8.08^{\mathrm{d}} \pm 1.1$ & $13.9^{\mathrm{b}} \pm 0.8$ & $10.9^{c} \pm 0.8$ \\
\hline $\begin{array}{l}\text { Insaturation } \\
\text { index }\end{array}$ & $161.1^{\mathrm{b}} \pm 11$ & $139.6^{\mathrm{cd}} \pm 9$ & $151.6^{c} \pm 11$ & $151.6^{c} \pm 12$ & $178.6^{\mathrm{a}} \pm 13$ & $177.4^{\mathrm{a}} \pm 12$ & $146.2^{c} \pm 9.7$ & $155.5^{c} \pm 10$ & $181.2^{\mathrm{a}} \pm 15$ & $147.1^{\mathrm{c}} \pm 9.8$ & $161.2^{b} \pm 12$ \\
\hline \multicolumn{12}{|c|}{ Triacylglycerols (\%) } \\
\hline $\mathrm{PPO}$ & $5.6^{b} \pm 0.5$ & $3.0^{c} \pm 0.4$ & $2.9^{c} \pm 0.4$ & $6.0^{\mathrm{ab}} \pm 0.5$ & $7.1^{a} \pm 0.5$ & $5.6^{\mathrm{b}} \pm 0.5$ & $7.1^{\mathrm{a}} \pm 0.7$ & $3.3^{c} \pm 0.5$ & $3.4^{\mathrm{c}} \pm 0.4$ & $4.2^{c} \pm 0.6$ & $5.1^{b} \pm 0.4$ \\
\hline $\mathrm{PPL}+\mathrm{OPPo}$ & $2.1 \pm 0.3$ & $2.5 \pm 0.3$ & $1.8 \pm 0.4$ & $3.1 \pm 0.2$ & $2.3 \pm 0.4$ & $2.3 \pm 0.4$ & $2.9 \pm 0.5$ & $1.9 \pm 0.3$ & $2.1 \pm 0.4$ & $2.2 \pm 0.5$ & $2.0 \pm 0.3$ \\
\hline POS & $2.2^{\mathrm{a}} \pm 0.4$ & $2.1^{\mathrm{a}} \pm 0.3$ & $1.6^{b} \pm 0.3$ & $2.6^{\mathrm{a}} \pm 0.3$ & $2.0^{\mathrm{a}} \pm 0.2$ & $2.9^{\mathrm{a}} \pm 0.5$ & $2.3^{\mathrm{a}} \pm 0.6$ & $2.3^{\mathrm{a}} \pm 0.4$ & $2.7^{\mathrm{a}} \pm 0.5$ & $2.3^{a} \pm 0.3$ & $2.2^{\mathrm{a}} \pm 0.4$ \\
\hline $\mathrm{POO}$ & $32.8^{\mathrm{ab}} \pm 2.3$ & $34.7^{\mathrm{a}} \pm 2.2$ & $33.6^{\mathrm{ab}} \pm 2.1$ & $32.3^{\mathrm{ab}} \pm 1.8$ & $26.9^{\mathrm{b}} \pm 1.9$ & $29.8^{\mathrm{b}} \pm 3.2$ & $32.4^{\mathrm{ab}} \pm 2.6$ & $30.6^{\mathrm{ab}} \pm 2.9$ & $30.8^{\mathrm{ab}} \pm 3.5$ & $32.2^{\mathrm{ab}} \pm 2.71$ & $32.6^{\mathrm{ab}} \pm 2.3$ \\
\hline $\mathrm{POL}+\mathrm{OOPo}$ & $6.5^{\mathrm{bc}} \pm 0.9$ & $4.8^{c} \pm 0.5$ & $5.3^{c} \pm 0.8$ & $7.9^{\mathrm{ab}} \pm 0.8$ & $8.9^{a} \pm 0.7$ & $6.2^{c} \pm 0.8$ & $9.5^{\mathrm{a}} \pm 0.6$ & $4.3^{c} \pm 0.9$ & $5.6^{c} \pm 0.5$ & $5.2^{c} \pm 0.4$ & $5.2^{c} \pm 0.9$ \\
\hline PLL + PoOL & $0.6^{\mathrm{b}} \pm 0.2$ & $0.5^{b} \pm 0.3$ & $0.4^{b} \pm 0.1$ & $0.3^{b} \pm 0.1$ & $0.5^{b} \pm 0.2$ & $0.3^{b} \pm 0.1$ & $0.9^{\mathrm{a}} \pm 0.2$ & $0.4^{b} \pm 0.1$ & $0.5^{b} \pm 0.2$ & $0.3^{b} \pm 0.1$ & $0.3^{b} \pm 0.1$ \\
\hline SSO & $0.2 \pm 0.0$ & $0.4 \pm 0.1$ & $0.3 \pm 0.1$ & $0.3 \pm 0.1$ & $0.3 \pm 0.1$ & $0.4 \pm 0.1$ & $0.5 \pm 0.2$ & $0.3 \pm 0.1$ & $0.4 \pm 0.1$ & $0.4 \pm 0.1$ & $0.3 \pm 0.1$ \\
\hline $\mathrm{SOO}$ & $4.9^{b} \pm 0.6$ & $4.4^{b} \pm 0.7$ & $2.8^{\mathrm{c}} \pm 0.9$ & $5.4^{b} \pm 0.8$ & $4.2^{b} \pm 0.8$ & $4.7^{b} \pm 0.6$ & $4.3^{b} \pm 0.8$ & $4.9^{b} \pm 1.1$ & $6.0^{\mathrm{a}} \pm 0.6$ & $5.2^{b} \pm 0.7$ & $4.9^{b} \pm 0.8$ \\
\hline $\mathrm{OOO}$ & $40.3^{\mathrm{ab}} \pm 1.8$ & $42.2^{\mathrm{a}} \pm 2.0$ & $41.4^{\mathrm{a}} \pm 3.1$ & $39.0^{\mathrm{ab}} \pm 2.2$ & $35.0^{c} \pm 2.9$ & $36.3^{c} \pm 3.4$ & $39.4^{\mathrm{ab}} \pm 3.1$ & $39.0^{\mathrm{ab}} \pm 2.7$ & $37.5^{b c} \pm 2.7$ & $42.4^{\mathrm{a}} \pm 3.1$ & $39.3^{\mathrm{ab}} \pm 2.8$ \\
\hline OOL & $11.6^{\mathrm{b}} \pm 1.7$ & $11.8^{b} \pm 2.0$ & $10.3^{b} \pm 1.8$ & $13.8^{b} \pm 1.9$ & $12.3^{b} \pm 2.3$ & $11.7^{b} \pm 2.5$ & $15.7^{\mathrm{a}} \pm 2.0$ & $10.0^{\mathrm{b}} \pm 1.9$ & $12.8^{b} \pm 2.3$ & $11.7^{b} \pm 2.1$ & $10.7^{b} \pm 1.8$ \\
\hline OLL & $0.2 \pm 0.0$ & $0.2 \pm 0.0$ & $0.1 \pm 0.0$ & $0.2 \pm 0.0$ & $0.6 \pm 0.2$ & $0.2 \pm 0.0$ & $0.4 \pm 0.1$ & $0.2 \pm 0.0$ & $0.1 \pm 0.0$ & $0.2 \pm 0.1$ & $0.2 \pm 0.1$ \\
\hline LLL & $0.6^{a} \pm 0.2$ & $0.7^{a} \pm 0.2$ & $0.4^{\mathrm{ab}} \pm 0.2$ & $0.6^{\mathrm{a}} \pm 0.1$ & $0.5^{a} \pm 0.2$ & $0.5^{a} \pm 0.2$ & $0.5^{\mathrm{a}} \pm 0.2$ & $0.3^{b} \pm 0.1$ & $0.5^{\mathrm{a}} \pm 0.2$ & $0.5^{a} \pm 0.2$ & $0.4^{a} \pm 0.1$ \\
\hline $\mathrm{AOO}$ & $0.4 \pm 0.1$ & $0.4 \pm 0.1$ & $0.3 \pm 0.1$ & $0.5 \pm 0.2$ & $0.4 \pm 0.1$ & $0.5 \pm 0.2$ & $0.3 \pm 0.1$ & $0.3 \pm 0.1$ & $0.4 \pm 0.2$ & $0.3 \pm 0.1$ & $0.3 \pm 0.1$ \\
\hline
\end{tabular}

Results expressed as $\mathrm{g}$ of fatty acid methyl ester $100 \mathrm{~g}^{-1}$ of oil; different letters in the same row indicate significantly different values $(p<0.001) ;{ }^{\mathrm{z}}$ Calculated as $\Sigma(\%$ monounsaturated

$+($ diunsaturated $\times 10)+($ triunsaturated $\times 20)) / 100$; Triacylglycerols molecular species abbreviations: 1,2-Dipalmitoyl-3-oleylglycerol (PPO); 1,2-Dipalmitoyl-3-linoleylglycerol (PPL); 1-Oleyl-2-palmitoyl-3-palmitoleylglycerol (OPPo); 1-Stearoyl-2-palmitoyl-3-oleylglycerol (POS); 2,3-Dioleyl-1-palmitoylglycerol (POO); palmitoyl-2-Oleyl-3-linoleylglycerol (POL); 1,2-Dioleyl-3-palmitoleylglycerol (OOPo); 1-Palmitoyl-2,3-dilinoleylglycerol (PLL); 1-Palmitoleyl-2-oleyl-3-linoleylglycerol (PoOL); 1,3-Distearoyl-2-oleylglycerol (SSO); 1-Stearoyl-2,3-dioleylglycerol (SOO); 1,2,3-Trioleylglycerol (OOO); 1-Oleyl-2,3-dilinoleyglycerol (OLL); 1,2-Dioleyl-3-linoleyglycerol (OOL); 1,2,3-Trilinoleylglycerol (LLL) and 1-Arachidil-2,3-dioleylglycerol (AOO) 
However, the relative fatty acid composition found in the different MEVOOs is different as compared to that reported by Portarena et al. for the same varieties [7]. They also investigated MEVOOs processed with the same plant and obtained from olives cultivated in the same area (Perugia, Italy). Differently from our results, they found that Moraiolo differed from Frantoio and Leccino oils in terms of oleic and linoleic acids percentages. These different outcomes can be related to the different environmental conditions thus suggesting a synergistic effect of genetic and environmental factors on the fatty acid composition. Mousavi et al. [20] investigated several olive cultivars, including Frantoio, Leccino, Coratina and Moraiolo, and demonstrated that the fatty acid profile of the oil was regulated by the interaction of environmental and genotype factors. It has been shown that both temperature and light play a role in modulating oleic acid content and the oleic acid/(palmitic + linoleic acids) ratio in the oil.

\subsection{Triacylglycerol Composition}

Although triacylglycerols (TAGs) have been widely utilized as markers of varietal and geographical origin of EVOO [42-47], the investigation of TAG profiles in Italian MEVOO is still limited [6,21,48-50]. To the best of our knowledge, the present work represents the first attempt at characterization of the TAGs profile in Italian MEVOO from Carboncella, Marzio, Maurino, Piantone di Falerone and Sargano di Fermo cultivars.

Significant variations in terms of TAG composition (Table 3) were found across the samples.

In all the oils, the most abundant TAG was OOO, followed by POO and OOL. They made up $80-90 \%$ of the total TAG profile. The remaining part of TAG matter was mainly formed of PPO, POL and SOO species, which accounted for about $10-15 \%$ of TAG profile.

Considering the most abundant TAGs, OOO ranged from $35.0 \pm 2.9$ to $42.4 \pm 3.1 \%$, POO from $26.9 \pm 1.9$ to $34.7 \pm 2.2 \%$, OOL from $10.0 \pm 1.9$ to $13.8 \pm 1.9 \%$. These results are comparable to those reported for some Italian monovarietal olive oils, including Coratina, Leccino and Pendolino $[48,50]$.

The POO and OOL levels weakly changed across the cultivars. Coratina oil presented the significant highest POO level $(34.7 \pm 2.2 \%)$, Marzio and Maurino the lowest one $(26.9 \pm 1.9 \%$ and $29.8 \pm$ $3.2 \%$, respectively), the remaining oils had comparable POO amounts accounting for about $30.6-32.8 \%$. Similarly, all the samples presented comparable OOL content (from 10.0 to $13.8 \%$ ), except for Moraiolo oil which had significantly higher levels $(15.7 \pm 2.0 \%)$ than all the other samples.

Unlike POO and OOL, OOO levels strongly varied among the oils. Although Marzio, Maurino and Pendolino showed similar OOO amounts, only Marzio and Maurino differed from all the other samples. They presented significantly $(p<0.001)$ lowest OOO levels. Conversely, Pendolino was not different form all the other samples, except than Coratina and Leccino, that presented the highest OOO levels. Our results are in good agreement with those of Giuffrè [48] who found higher OOO levels in Coratina than in Pendolino oils.

Congruently to what was observed for oleic acid content, the OOO level enables the discrimination of Marzio and Maurino oils from all the others. Anyway, on the basis of OOO levels it was not possible to differentiate Pendolino from the other oils. These outcomes lead us to suppose that the investigation of TAG profiles provides more restrictive information on oil discrimination than that derived from analysis of total fatty acid profiles. In fact, variation of TAG profiles among MEVOOs could better reflect the specific metabolic behavior of each cultivar. The biosynthesis of TAG in the olive fruit involves additional pathways with respect to the biosynthesis of fatty acids. This assumption can also be reinforced by considering the variation of TAG species formed by the combination of oleic acid and the most abundant saturated fatty acids, such as palmitic and stearic acids. Although stearic acid clustered the oils into two groups (Carboncella, Coratina, Marzio, Moraiolo, Rosciola vs. the other MEVOOs), the level of the main molecular species containing stearic, SOO and POS, enabled the discrimination of Frantoio oil from all the others, since Frantoio oil showed the lowest SOO and POS amounts. Similarly, although the highest levels of palmitic and the lowest level of oleic acids 
distinguished Marzio, Maurino and Pendolino oils, the highest PPO level differentiated Marzio and Moraiolo from the rest of the oils.

\subsection{Oxidative Stability, Total Phenols Content and Phenolic Profile}

Table 4 reports the oxidative stability, total phenolic content and the amount of the single phenolic compounds identified in the oil samples.

The induction time of the oils ranged from 17.5 (Leccino) to 29.5 (Coratina) hours. Coratina and Rosciola showed the significantly highest stability.

The total amount of phenols determined by Folin-Ciocalteu assay ranged from 153 to $396 \mathrm{mg} \mathrm{kg}^{-1}$. Marzio oil showed the significantly highest content of phenols $\left(396 \mathrm{mg} \mathrm{kg}^{-1}\right)$ followed by Carboncella (323.1 mg kg${ }^{-1}$ ) and Pendolino $\left(307.6 \mathrm{mg} \mathrm{kg}^{-1}\right)$. Leccino showed the significantly lowest amount of phenols (153 mg kg${ }^{-1}$ ), while Rosciola, Coratina and Maurino oils showed comparable phenolic content. The total phenol content values agree with the ones reported by other studies conducted on MEVOOs. Baiano et al. [51] reported values between 133 and $322 \mathrm{mg} \mathrm{kg}^{-1}$ for olive oils from orchards located in the north of Apulia region, Negro et al. [13] presented values between 138 and $278 \mathrm{mg} \mathrm{kg}^{-1}$ for oils produced in the province of Lecce (Apulia, Italy), whereas Ninfali et al. [52] reported values in the range of 50-236 mg kg-1 for plants cultivated in the center of Italy. Ricciutelli et al. [53] indicated values ranging from 136 to $437 \mathrm{mg} \mathrm{kg}^{-1}$ for commercial EVOOs. Rotondi et al. [5] reported mean values for total phenolic content ranging from 327 to $646 \mathrm{mg} \mathrm{kg}^{-1}$ (obtained for the cultivars Biancolilla and Bianchera, respectively) in 16 Italian cultivars considered more representative. However, it is to be reminded that the total phenol content is strictly related to many factors, such as the olive harvesting time, oil extraction techniques or quantification methodologies [54]. Many studies, indeed, showed that the pedoclimatic and technological aspects are the main parameters influencing the total phenol content in EVOOs $[9,55,56]$. The genotype may also highly influence the oil phenolic content; Negro et al. [13] indicated that genotype may be responsible for about $50 \%$. The phenolic content is usually related to the shelf-life and the oxidative stability of olive oil, although polar phenolic substances are also responsible for the olive oil flavor related to bitterness, astringency and pungency. Bitterness in olive oil is strictly due to the content of oleuropein glucoside and its aglycon [23]. Oils obtained from olive fruits rich in phenolics, e.g., Marzio MEVOO, are expected to be more bitter and pungent than the others. The EU legislation about the health claim on olive oil phenolic substances requires accurate measurements of the level of specific phenolic compounds in olive oil. In the current paper, twelve phenolic compounds were also specifically identified and quantified using HPLC coupled to DAD and a mass spectrometry instrument. The main phenolic alcohols found in the MEVOOs were 3,4-DHPEA and $p$-HPEA. Their concentration is usually low in the fresh oils, but increases during storage [32,57-59] due to the lysis of the secoiridoids, such as the dialdehydic forms of decarboxymethyl elenolic acid linked to 3,4-DHPEA (3,4-DHPEA-EDA, oleacein) and to $p$-HPEA ( $p$-HPEA-EDA, oleocanthal), and oleuropein aglycon (3,4-DHPEA-EA) that release 3,4-DHPEA and $p$-HPEA, respectively. As shown in Table 4, the content of 3,4-DHPEA ranged between 1.8 to $18.5 \mathrm{mg} \mathrm{kg}^{-1}$ for Pendolino and Leccino, respectively, while $p$-HPEA ranged between 2.2 and $16.8 \mathrm{mg} \mathrm{kg}^{-1}$ for Moraiolo and Rosciola. Other studies conducted on Leccino MEVOOs reported values of $13.8 \mathrm{mg} \mathrm{kg}^{-1}$ [15] and $0.72-1.37 \mathrm{mg} \mathrm{kg}^{-1}$ [57] for 3,4-DHPEA content and $20.2 \mathrm{mg} \mathrm{kg}^{-1}$ [15] and from 1.08 to $2.22 \mathrm{mg} \mathrm{kg}^{-1}$ [60] for $p$-HPEA, indicating a certain variability for these phenolics. Ricciutelli et al. [53] have identified a mean value of $9.9 \mathrm{mg} \mathrm{kg}^{-1}$ oil and $13.4 \mathrm{mg} \mathrm{kg}^{-1}$ oil for 3,4-DHPEA and $p$-HPEA, respectively, in commercial EVOOs. Among phenolic alcohols, 3,4-DHPEA is worthy of investigation for its nutraceutical properties [61], so the cultivars that showed the highest contents (mainly Leccino, Rosciola and Carboncella) are worthy of interest to obtain EVOO blends with increased nutraceutical properties. Thus 3,4-DHPEA has been indicated by Carrasco-Pancorbo et al. [62] as the main contributor among polyphenolic compounds for oxidative stability of olive oils. Vanillic acid and vanillin were found at very low concentrations in all samples (0.2-1.34 $\mathrm{mg} \mathrm{kg}^{-1}$ and $0.50-3.2 \mathrm{mg} \mathrm{kg}^{-1}$ of oil, respectively), with small differences among studied oils. Only in Moraiolo and Piantone di Falerone was vanillic acid not detected. These values 
are in accordance with the ones found by Gambacorta et al. [60] in MEVOOs investigated (including Coratina, Frantoio and Leccino varieties) and also Ricciutelli et al. [53] indicated an average value for vanillic acid of $0.3 \mathrm{mg} \mathrm{kg}^{-1}$ for commercial EVOOs. The secoiridoid compounds are in general the most abundant phenolic compounds present in fresh oils but during shelf life their content decreases [32]. Rosciola showed the highest content for 3,4-DHPEA-EDA and $p$-HPEA-EDA (120 and $105 \mathrm{mg} \mathrm{kg}^{-1}$, respectively). Other varieties such as Carboncella, Coratina, Moraiolo and Piantone di Falerone showed a good content of both the phenols compared to the others. Coratina, one of variety appreciated for the high phenols content, showed 103 and $64.4 \mathrm{mg} \mathrm{kg}^{-1}$ of 3,4-DHPEA-EDA and $p$-HPEA-EDA, respectively. Frantoio, Marzio, Maurino, Pendolino and Sargano di Fermo cultivars showed an average content of these two compounds compared to Coratina, while Leccino presented the lowest content (21 and $16.7 \mathrm{mg} \mathrm{kg}^{-1}$ for 3,4-DHPEA-EDA and $p$-HPEA-EDA, respectively). $p$-HPEA-EDA deserves great attention because of its several nutraceutical properties reported by many studies and reviews [63,64]; it showed wide concentration ranges in olive oils. Backhouche et al. [65] reported values from 3.3 to $4.6 \mathrm{mg} \mathrm{kg}^{-1}$ depending on the geographical region, for the Spanish Arbequina variety, while much higher values $\left(104.0 \pm 1.8 \mathrm{mg} \mathrm{kg}^{-1}\right)$ were reported for the same variety by Vidal et al., in a study aimed to obtain oils rich in oleacein and oleocanthal [66]. This big difference in concentration values can also be explained largely with the different methods and reference standards used to quantify secoiridoid derivatives. Backhouche et al. [65] used electrospray ionization with time of flight mass spectrometer detection and oleuropein as calibration standard, that gave a very different response than tyrosol [65], that instead was used as an external standard by Vidal et al. with an ultraviolet detection at $280 \mathrm{~nm}$ [66]. Concentrations from 38.7 to $72.5 \mathrm{mg} \mathrm{kg}^{-1}$, depending on the different processing conditions, were reported for the Spanish Picual variety [67]. Fuentes et al. [68] reported concentrations from 25 to $77 \mathrm{mg} \mathrm{kg}^{-1}$ for Chilean oils, Negro et al. [13] instead indicated values from 4.3 to $103.4 \mathrm{mg} \mathrm{kg}^{-1}$ for Apulian varieties. Considering the important role of $p$-HPEA-EDA in the nutraceutical properties of EVOO, Rosciola and Moraiolo genotypes represent the best sources among varieties investigated, with concentrations of $105 \pm 6.9$ and $82.3 \pm 6.8 \mathrm{mg} \mathrm{kg}^{-1}$, respectively.

In all varieties, the dialdehydic form of ligstroside aglycon (DLA) was coeluted with the oxidized form of $p$-HPEA-EDA and the highest content was found in Marzio (147 mg kg-1) followed by Pendolino and Sargano di Fermo (126 and $101 \mathrm{mg} \mathrm{kg}^{-1}$, respectively), while Leccino and Coratina showed lower content (49.3 and $51.2 \mathrm{mg} \mathrm{kg}^{-1}$, respectively). The last two secoiridoids in terms of elution time were 3,4-DHPEA-EA and $p$-HPEA-EA found in all varieties. The contents of 3,4-DHPEA-EA was higher in Marzio (106 mg kg-1), followed by Pendolino $\left(72.5 \mathrm{mg} \mathrm{kg}^{-1}\right)$, Maurino $\left(57.1 \mathrm{mg} \mathrm{kg}^{-1}\right.$ ) and Carboncella (53.5 mg kg-1), while the Leccino variety showed the lowest $\left(3.8 \mathrm{mg} \mathrm{kg}^{-1}\right)$. For some varieties Negro et al. [13] reported higher values, in the range of $33.8-152.3 \mathrm{mg} \mathrm{kg}^{-1}$, while similar values were reported in the oils analyzed by Ragusa et al. [15]. Normally 3,4-DHPEA-EA tends to decrease from drupes to malaxation paste and to the final oil [13]. $p$-HPEA-EA was the last secoiridoid quantified, its content ranged between 2.9 and $23.3 \mathrm{mg} \mathrm{kg}^{-1}$, for Leccino and Marzio, respectively. In this case $p$-HPEA-EA content is similar to the values reported by Negro et al. [13] and slightly lower than the ones reported by Ragusa et al. [15]. The flavonoids that can usually be found in EVOO extracts are luteolin, apigenin and sometimes methoxyluteolin. This class of compounds is known to have many beneficial biological effects including anti-inflammatory, antioxidant and estrogenic activity [69]. Methoxyluteolin was found in traces only in the Moraiolo variety, while luteolin ranged between 2.65 and $8.3 \mathrm{mg} \mathrm{kg}^{-1}$ for Piantone di Falerone and Carboncella, respectively. Similar values were found by García-Martínez et al. [69] in Spanish EVOOs (1.66-6.21 mg kg-1) and by Tuberoso et al. [66] in varieties from Sardinia region (Italy) $\left(0.2-7.1 \mathrm{mg} \mathrm{kg}^{-1}\right)$. Luteolin was not detected in Leccino and Maurino varieties. Finally, apigenin was found with an average content of about $2 \mathrm{mg} \mathrm{kg}-1$, in accordance with the values reported for EVOOs in several other studies [60,69,70]. Marzio and Rosciola MEVOOs complied with the minimum content of the specific phenolic substances required to acknowledge the health claim (250 $\left.\mathrm{mg} \mathrm{kg}^{-1}\right)$ [71]. 
Table 4. Oxidative stability, total phenols content and phenolic profile of the eleven monovarietal extra virgin olive oils investigated.

\begin{tabular}{|c|c|c|c|c|c|c|c|c|c|c|c|}
\hline & Carboncella & Coratina & Frantoio & Leccino & Marzio & Maurino & Moraiolo & $\begin{array}{l}\text { Piantone di } \\
\text { Falerone }\end{array}$ & Pendolino & Rosciola & $\begin{array}{c}\text { Sargano di } \\
\text { Fermo }\end{array}$ \\
\hline $\begin{array}{c}\text { Oxidative } \\
\text { stability (h) }\end{array}$ & $24.3^{\mathrm{cd}} \pm 0.4$ & $29.5^{\mathrm{a}} \pm 0.9$ & $19.8^{\mathrm{f}} \pm 0.4$ & $17.5^{g} \pm 0.7$ & $24.2^{\mathrm{cd}} \pm 0.5$ & $21^{\text {ef }} \pm 1.1$ & $26.3^{b c} \pm 0.4$ & $22.3^{\text {ed }} \pm 0.7$ & $20.3^{\mathrm{ef}} \pm 0.6$ & $27.8^{\mathrm{ab}} \pm 0.8$ & $19.6^{\mathrm{f}} \pm 0.6$ \\
\hline $\begin{array}{l}\text { Total phenols } \\
\text { (mg gallic acid } \\
\mathrm{kg}^{-1} \text { oil) }\end{array}$ & $323^{b} \pm 10$ & $283^{\mathrm{cd}} \pm 5.6$ & $209^{\mathrm{f}} \pm 5.2$ & $153 \mathrm{~g} \pm 5.9$ & $396^{\mathrm{a}} \pm 20$ & $272^{\mathrm{d}} \pm 8.2$ & $243^{\mathrm{e}} \pm 5.2$ & $228^{\text {ef }} \pm 10$ & $308^{\mathrm{bc}} \pm 5.7$ & $292^{\mathrm{cd}} \pm 9.4$ & $208^{f} \pm 6.5$ \\
\hline \multicolumn{12}{|c|}{ Phenolic compounds (mg kg${ }^{-1}$ oil) } \\
\hline 3,4-DHPEA & $15.1^{\mathrm{b}} \pm 0.8$ & $10.5^{c} \pm 0.5$ & $3.3^{\mathrm{fg}} \pm 0.1$ & $18.5^{\mathrm{a}} \pm 1.4$ & $6.1^{\mathrm{e}} \pm 0.1$ & $4.9^{\mathrm{ef}} \pm 0.2$ & $4.7^{\text {ef }} \pm 0.1$ & $8.2^{d} \pm 0.3$ & $1.8^{g} \pm 0.1$ & $15.7^{\mathrm{b}} \pm 0.9$ & $4.5^{\mathrm{ef}} \pm 0.1$ \\
\hline$p$-HPEA & $3.1^{\text {ef }} \pm 0.1$ & $8.2^{c} \pm 0.3$ & $4.4^{\text {def }} \pm 0.6$ & $13.6^{\mathrm{b}} \pm 1.3$ & $6.0^{\mathrm{e}} \pm 0.5$ & $2.8^{\mathrm{ef}} \pm 0.2$ & $2.2^{\mathrm{f}} \pm 0.3$ & $5.1 \mathrm{de} \pm 0.3$ & $4.3^{\text {def }} \pm 0.5$ & $16.8^{a} \pm 1.1$ & $3.5^{\mathrm{def}} \pm 0.5$ \\
\hline Vanillic acid & $0.29^{c} \pm 0.3$ & $0.52^{c} \pm 0.1$ & $1.1^{\mathrm{a}} \pm 0.1$ & $0.92^{b} \pm 0.1$ & $0.82^{b} \pm 0.1$ & $1.34^{\mathrm{a}} \pm 0.2$ & nd & nd & $0.49^{c} \pm 0.1$ & $0.63^{b c} \pm 0.1$ & $0.2^{\mathrm{c}} \pm 0.01$ \\
\hline Vanillin & $0.56^{\mathrm{d}} \pm 0.1$ & $1.48^{\mathrm{b}} \pm 0.2$ & $1.3^{\mathrm{b}} \pm 0.2$ & $3.2^{\mathrm{a}} \pm 0.2$ & $1.32^{b} \pm 0.2$ & $0.81^{\mathrm{c}} \pm 0.1$ & $0.92^{c} \pm 0.1$ & $1.63^{b} \pm 0.3$ & $0.95^{c} \pm 0.2$ & $1.23^{\mathrm{b}} \pm 0.2$ & $0.50^{\mathrm{d}} \pm 0.1$ \\
\hline 3,4-DHPEA-EDA & $86.4^{\mathrm{c}} \pm 7.6$ & $103^{\mathrm{b}} \pm 8.2$ & $30.9 \mathrm{~g} \pm 2.8$ & $21.0^{\mathrm{h}} \pm 3.1$ & $72.9^{\mathrm{d}} \pm 6.2$ & $37.2^{\mathrm{ef}} \pm 2.1$ & $80.1^{\mathrm{cd}} \pm 8.6$ & $74.4^{\mathrm{d}} \pm 4.9$ & $50.8^{\mathrm{e}} \pm 3.1$ & $120^{\mathrm{a}} \pm 9.6$ & $41.9^{\text {ef }} \pm 3.9$ \\
\hline$p$-HPEA-EDA & $67.3^{\mathrm{cd}} \pm 5.5$ & $64.4^{\mathrm{cd}} \pm 3.5$ & $31.2^{\mathrm{e}} \pm 1.8$ & $16.7^{\mathrm{f}} \pm 2.3$ & $56.8^{\mathrm{d}} \pm 4.8$ & $24.8^{\text {ef }} \pm 2.8$ & $82.3^{\mathrm{b}} \pm 6.8$ & $71.8^{\mathrm{bc}} \pm 5.8$ & $32.6^{\mathrm{e}} \pm 1.4$ & $105^{\mathrm{a}} \pm 6.9$ & $35.5^{\mathrm{e}} \pm 3.8$ \\
\hline 3,4-DHPEA-EA & $53.5^{\mathrm{cd}} \pm 3.6$ & $32.4^{\mathrm{f}} \pm 2.4$ & $23.2^{g} \pm 3.6$ & $3.8^{\mathrm{h}} \pm 0.3$ & $106^{\mathrm{a}} \pm 9.2$ & $57.1^{c} \pm 3.9$ & $20.5^{g} \pm 2.3$ & $43.2^{\mathrm{e}} \pm 4.1$ & $72.5^{b} \pm 2.8$ & $46.6^{\mathrm{de}} \pm 2.9$ & $22.1^{g} \pm 1.6$ \\
\hline$p$-HPEA-EA & $16.0^{\mathrm{b}} \pm 0.1$ & $11.6^{b c} \pm 1.8$ & $14.7^{b} \pm 0.7$ & $2.9^{\mathrm{d}} \pm 1.2$ & $23.3^{\mathrm{a}} \pm 2$ & $11.5^{b c} \pm 1.2$ & $5.5^{\mathrm{d}} \pm 0.9$ & $16.4^{b} \pm 2.1$ & $11.6^{\mathrm{bc}} \pm 1.6$ & $14.7^{\mathrm{b}} \pm 0.5$ & $7.1^{\mathrm{cd}} \pm 1.1$ \\
\hline Luteolin & $8.3^{\mathrm{a}} \pm 1.1$ & $5.45^{c} \pm 0.5$ & $6.9^{b} \pm 2.3$ & nd & $5.75^{c} \pm 0.8$ & nd & $5.45^{\mathrm{c}} \pm 1.1$ & $2.65^{\mathrm{d}} \pm 0.3$ & $4.25^{c} \pm 0.6$ & nd & $6.24^{b} \pm 0.5$ \\
\hline Apigenin & $2.65^{\mathrm{a}} \pm 0.1$ & $2.05^{b} \pm 0.3$ & $1.9^{b} \pm 0.4$ & $1.76^{b} \pm 0.2$ & $2.03^{b} \pm 0.2$ & $1.85^{b} \pm 0.3$ & $1.87^{b} \pm 0.2$ & $0.95^{c} \pm 0.2$ & $0.84^{c} \pm 0.1$ & $3.00^{\mathrm{a}} \pm 0.4$ & $2.08^{b} \pm 0.1$ \\
\hline
\end{tabular}

Oxidative stability (hours, induction time in response to force oxidation); phenolic substances abbreviation: 3,4-DHPEA: 3,4-Dihydroxyphenylethanol; $p$-HPEA: $p$-hydroxyphenylethanol; 3,4-DHPEA-EDA: dialdehydic form of decarboxymethyl elenolic acid linked to 3,4-DHPEA; $p$-HPEA-EDA: dialdehydic form of decarboxymethyl elenolic acid linked to $p$-HPEA; $p$-HPEA-EDA-Ox.: $p$-HPEA-EDA oxidized; 3,4-DHPEA-EA: oleuropein aglycon; $p$-HPEA-EA: ligstroside aglycon. Different letters (between a and h) in the same row indicate significantly different values $(p<0.001)$. 


\subsection{Sensory Properties of Oils and Relationship between Sensory Sensations and Chemical Composition}

The bi-plot from PCA illustrates the mutual relationships between samples and discriminating chemical and sensory variables (Figure 1).

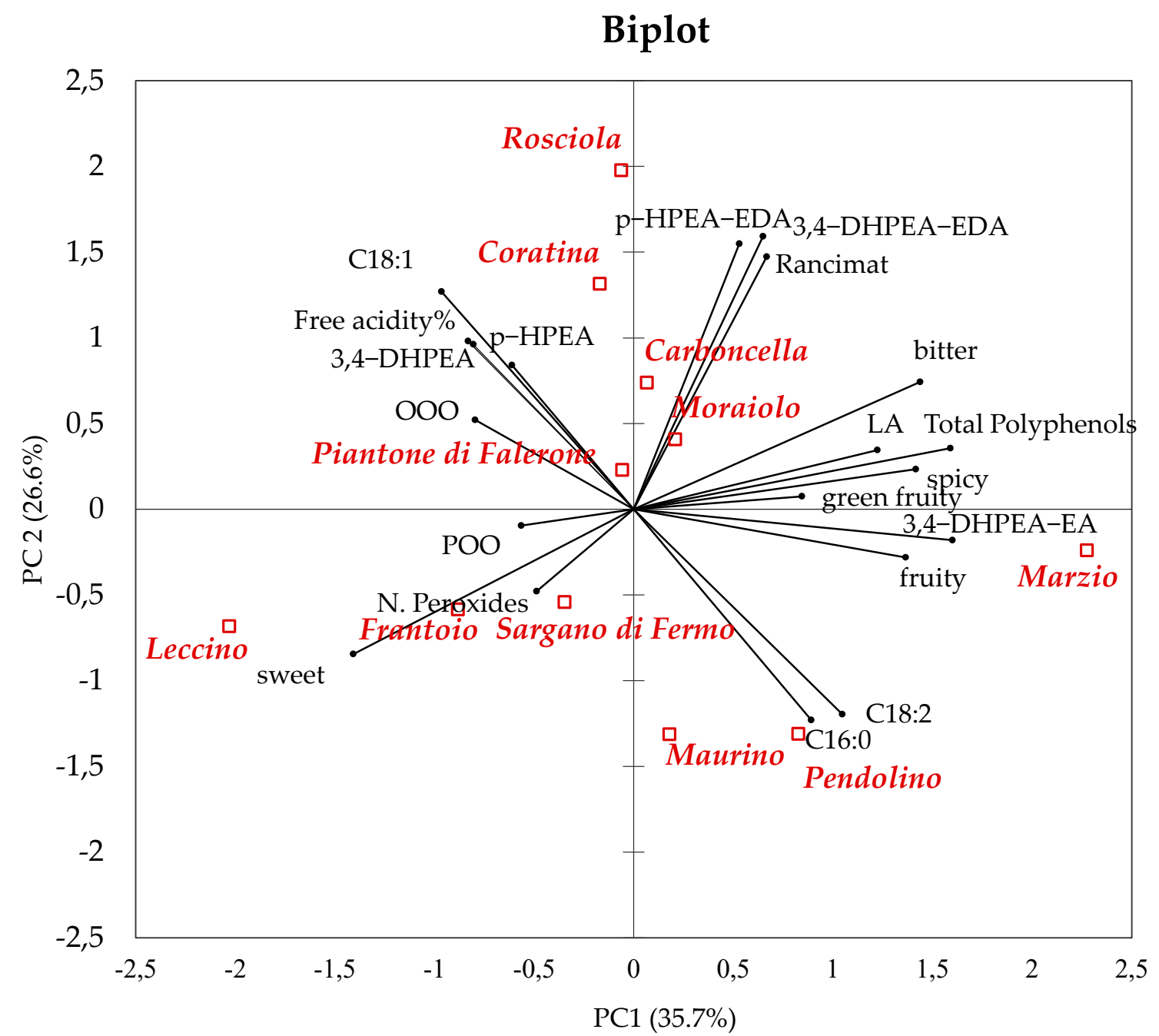

Figure 1. Bi-plot from principal component analysis (PCA) reporting principal components 1 and 2 (PC1 and PC2, respectively) with the loadings of selected chemical and sensory variables and the scores (oil samples).

Legend: 3,4-DHPEA: 3,4-Dihydroxyphenylethanol; p-HPEA: p-Hydroxyphenylethanol; 3,4-DHPEA-EDA: dialdehydic form of decarboxymethyl elenolic acid linked to 3,4-DHPEA; p-HPEA-EDA: dialdehydic form of decarboxymethyl elenolic acid linked to $p$-HPEA; 3,4-DHPEA-EA: oleuropein aglycon; $p$-HPEA-EA: ligstroside aglycon; C16:0: palmitic acid; C18:1: oleic acid; C18:2: linoleic acid; total phenols (determined by Folin-Ciocalteu method); OOO: 1,2,3-Trioleylglycerol; POO: 2,3-Dioleyl-1-palmitoylglycerol.

The first two components in the PCA accounted for $62.3 \%$ of total variance, with the first component (PC1) explaining 35.7\%.

Samples were distributed on the PC1 according to a contraposition between bitter, greenly fruity and spicy (positively correlated on PC1) and sweet (negatively correlated on PC1). Along PC1, bitter, greenly fruity and pungency showed a high correlation with total phenols compounds, $p$-HPEA-EA and with the amount of 3,4-DHPEA-EA. This is in agreement with previous studies clearly showing that 3,4-DHPEA-EA is crucial for the perception of bitter and pungency in EVOOs [72]. The positive 
correlation observed on the bi-plot between oxidative stability and total phenols has been previously documented [32].

Instead, sweet was positively correlated with peroxide index and POO; this finding may be explained by the lower phenols content that protect against the oxidation phenomena and that contribute to pungency/bitterness, attributes lacking in sweet oils. As the correlation on PC2 positively increased, both the oxidative stability and the amount of 3,4-DHPEA-EDA and $p$-HPEA-EDA increased. Acidity, amount of 3,4-DHPEA, $p$-HPEA and oleic acid (C18:1)\%, had high positive loadings on PC2.

The content of $p$-HPEA and 3,4-DHPEA, that is known to increase with oil aging, strongly characterized Coratina; these phenols correlated with FA, that in fact also derives from hydrolytic processes.

On PC2, palmitic acid (C16:0) and linoleic acid (C18:2) had negative loadings as well as PV and POO (despite lower loadings).

\section{Conclusions}

In the present paper, a chemical and sensory characterization was conducted on eleven MEVOOs from olives grown in the same experimental olive orchard, with the same conditions (fertilization, irrigation), and processed with the same technology. Thus, differences found across MEVOOs were attributable only to the factors related to the genetic background of the olive cultivar.

The findings highlighted the impact of genetic background of the olive on the sensory attributes, fatty acid, TAG and phenolic compositions of the oils.

Across the investigated oils, Marzio stood out significantly from the rest resulting in the most bitter, pungent, fruity and the richest in phenolic compounds. The high phenolic level conferred it a good oxidative stability although it presented the highest unsaturation index.

The study represents a scientific contribution enriching the database of Italian olive oil cultivars providing information on the role of the cultivar in the differentiation of the chemical composition of the different MEVOOs, by excluding bias associated to the pedoclimatic influence and technological production conditions.

Author Contributions: Conceptualization, D.F., D.P., G.D.L. and N.G.F.; methodology, G.D.L. and M.P.; formal analysis, M.P. and E.B.; data curation, G.D.L., D.F., M.P. and S.S.; writing-original draft preparation, G.D.L., M.P., D.P. and D.F.; writing-review and editing, E.B. and S.S.; supervision, D.P. and N.G.F.; project administration, D.P. and N.G.F.; funding acquisition, N.G.F. All authors have read and agreed to the published version of the manuscript.

Funding: This work was supported by the Polytechnic University of Marche (Grant, Frega, Ricerca di Ateneo 2018).

Conflicts of Interest: The authors declare no conflict of interest.

\section{References}

1. Cacchiarelli, L.; Carbone, A.; Laureti, T.; Sorrentino, A. The value of the certifications of origin: A comparison between the Italian olive oil and wine markets. Brit. Food J. 2016, 118, 824-839. [CrossRef]

2. García-González, D.L.; Aparicio, R. Research in olive oil: Challenges for the near future. J. Agric. Food Chem. 2010, 58, 12569-12577. [CrossRef] [PubMed]

3. Carbone, A.; Cacchiarelli, L.; Sabbatini, V. Exploring quality and its value in the Italian olive oil market: A panel. Agric. Food Econ. 2018, 6. [CrossRef]

4. International Olive Oil Council. The International Market. 2019. Available online: http://www. internationaloliveoil.org (accessed on 7 June 2020).

5. Rotondi, A.; Magli, M.; Morrone, L.; Alfei, B.; Pannelli, G. Italian National Database of Monovarietal Extra Virgin Olive Oils. In The Mediterranean Genetic Code - Grapevine and Olive; Poljuha, D., Sladonja, B., Eds.; IntechOpen: London, UK, 2013; pp. 179-200. [CrossRef]

6. Blasi, F.; Pollini, L.; Cossignani, L. Varietal Authentication of Extra Virgin Olive Oils by Triacylglycerols and Volatiles Analysis. Foods 2019, 8, 58. [CrossRef] [PubMed] 
7. Portarena, S.; Farinelli, D.; Lauteri, M.; Famiani, F.; Esti, M.; Brugnoli, E. Stable isotope and fatty acid compositions of monovarietal olive oils: Implications of ripening stage and climate effects as determinants in traceability studies. Food Control 2015, 57, 129-135. [CrossRef]

8. Rotondi, A.; Alfei, B.; Magli, M.; Pannelli, G. Influence of genetic matrix and crop year on chemical and sensory profiles of Italian monovarietal extra-virgin olive oils. J. Sci. Food Agric. 2010, 90, 2641-2648. [CrossRef]

9. Klikarová, J.; Česlová, L.; Kalendová, P.; Dugo, P.; Mondello, L.; Cacciola, F. Evaluation of Italian extra virgin olive oils based on the phenolic compounds composition using multivariate statistical methods. Eur. Food Res. Technol. 2020, 246, 1241-1249. [CrossRef]

10. Campus, M.; Sedda, P.; Delpiano, D.; Secci, S.; Damasco, G.; Zurru, R.; Bandino, G. Variability in composition, sensory profiles and volatile compounds of Sardinian monovarietal virgin olive oils grown in different areas. Riv. Ital. Sostanze Grasse 2013, 90, 237-248.

11. Cecchi, T.; Passamonti, P.; Alfei, B.; Cecchi, P. Monovarietal extra virgin olive oils from the Marche region, Italy: Analytical and sensory characterization. Int. J. Food Prop. 2011, 14, 483-495. [CrossRef]

12. Pacetti, D.; Boarelli, M.C.; Giovannetti, R.; Ferraro, S.; Conti, P.; Alfei, B.; Caprioli, G.; Ricciutelli, M.; Sagratini, G.; Fedeli, D.; et al. Chemical and Sensory Profiling of Monovarietal Extra Virgin Olive Oils from the Italian Marche Region. Antioxidants 2020, 9, 330. [CrossRef]

13. Negro, C.; Aprile, A.; Luvisi, A.; Nicolì, F.; Nutricati, E.; Vegine, M.; Miceli, A.; Blando, F.; Sabella, E.; De Bellis, L. Phenolic Profile and Antioxidant Activity of Italian Monovarietal Extra Virgin Olive Oils. Antioxidants 2019, 8, 161. [CrossRef] [PubMed]

14. Piscopo, A.; De Bruno, A.; Zappia, A.; Ventre, C.; Poiana, M. Characterization of monovarietal olive oils obtained from mills of Calabria region (Southern Italy). Food Chem. 2016, 213, 313-318. [CrossRef]

15. Ragusa, A.; Centanze, C.; Grasso, M.E.; Latronico, M.F.; Mastrangelo, P.F.; Fanizzi, F.P.; Maffia, M. Composition and Statistical Analysis of Biophenols in Apulian Italian EVOOs. Foods 2017, 6, 90. [CrossRef] [PubMed]

16. Rotondi, A.; Lapucci, C.; Morrone, L.; Neri, L. Autochthonous cultivars of Emilia Romagna region and their clones: Comparison of the chemical and sensory properties of olive oils. Food Chem. 2017, 224, 78-85. [CrossRef] [PubMed]

17. Laincer, F.; Iaccarino, N.; Amato, J.; Pagano, B.; Pagano, A.; Tenore, G.; Randazzo, A. Characterization of monovarietal extra virgin olive oils from the province of Béjaïa (Algeria). Food Res. Int. 2016, 89, 1123-1133. [CrossRef]

18. Lukić, I.; Horvat, I.; Godena, S.; Krapac, M.; Lukić, M.; Vrhovsek, U.; Brkić Bubola, K. Towards understanding the varietal typicity of virgin olive oil by correlating sensory and compositional analysis data: A case study. Food Res. Int. 2018, 112, 78-89. [CrossRef]

19. Issaoui, M.; Flamini, G.; Brahmi, F.; Dabbou, S.; Hassine, K.B.; Taamali, A.; Hammami, M. Effect of the growing area conditions on differentiation between Chemlali and Chétoui olive oils. Food Chem. 2010, 119, 220-225. [CrossRef]

20. Mousavi, S.; de la Rosa, R.; Moukhli, A.; Mariotti, R.; Torres, M.; Pierantozzi, P.; Stanzione, V.; Mastio, V.; Zaher, H.; Ayoub, S.; et al. Plasticity of fruit and oil traits in olive among different environments. Sci. Rep. 2019, 9, 16968. [CrossRef] [PubMed]

21. Vichi, S.; Pizzale, L.; Conte, L.S. Stereospecific distribution of fatty acids in triacylglycerols of olive oils. J. Lipid Sci. Technol. 2007, 109, 72-78. [CrossRef]

22. Campestre, C.; Angelini, G.; Gasparri, C.; Angerosa, F. The Compounds Responsible for the Sensory Profile in Monovarietal Virgin Olive Oils. Molecules 2017, 22, 1833. [CrossRef]

23. Aparicio, R.; Luna, G. Characterisation of monovarietal virgin olive oils. Eur. J. Lipid Sci. Technol. 2002, 104, 614-627. [CrossRef]

24. Bruno, L.; Picardi, E.; Pacenza, M.; Chiappetta, A.; Muto, A.; Gagliardi, O.; Muzzalupo, I.; Pesole, G.; Bitonti, M.B. Changes in gene expression and metabolic profile of drupes of Olea europaea L. cv Carolea in relation to maturation stage and cultivation area. BMC Plant Biol. 2019, 19, 428. [CrossRef]

25. Uceda, M.; Frias, L. Harvest dates. Evolution of the fruit oil content, oil composition and oil quality. In Proceedings of the Segundo Seminario Oleicola Internacional, Cordoba, Spain, 6-17 October 1975; pp. 125-130.

26. International Olive Council (IOC). Sensory Analysis of Olive Oil-Method for the Organoleptic Assessment of Virgin Olive Oil; COI/T.20/Doc. No 15/Rev. 10; International Olive Council (IOC): Madrid, Spain, 2018. 
27. International Olive Oil Council. Sensory Analysis of Olive Oil. Standard. Glass for Oil Tasting. 2007. Available online: http://www.internationaloliveoil.org (accessed on 7 June 2020).

28. Christie, W.W. Gas chromatography-mass spectrometry methods for structural analysis of fatty acids. Lipids 1998, 33, 343-353. [CrossRef] [PubMed]

29. Sweeley, C.C.; Bentley, R.; Makita, M.; Wells, W.W. Gas-Liquid Chromatography of Trimethylsilyl Derivatives of Sugars and Related Substances. J. Am. Chem. Soc. 1963, 85, 2497-2507. [CrossRef]

30. Boselli, E.; Pacetti, D.; Lucci, P.; Di Lecce, G.; Frega, N.G. Supplementation with high-oleic sunflower oil and $\alpha$-tocopheryl acetate: Effects on pork meat lipids. Eur. J. Lipid Sci. Technol. 2008, 110, 381-391. [CrossRef]

31. Ruiz-Samblás, C.; González-Casado, A.; Cuadros-Rodríguez, L. Triacylglycerols Determination by High-temperature Gas Chromatography in the Analysis of Vegetable Oils and Foods: A Review of the Past 10 Years. Crit. Rev. Food Sci. Nutr. 2015, 55, 1618-1631. [CrossRef]

32. Boselli, E.; Di Lecce, G.; Strabbioli, R.; Pieralisi, G.; Frega, N.G. Are virgin olive oils obtained below $27^{\circ} \mathrm{C}$ better than those produced at higher temperatures? LWT Food Sci. Technol. 2009, 42, 748-757. [CrossRef]

33. Singleton, V.L.; Rossi, A.J. Colorimetry of Total Phenolics with Phosphomolybdic-Phosphotungstic Acid Reagents. Am. J. Enol. Vitic. 1965, 16, 144-158.

34. Fiori, F.; Di Lecce, G.; Boselli, E.; Pieralisi, G.; Frega, N.G. Effects of olive paste fast preheating on the quality of extra virgin olive oil during storage. LWT Food Sci. Technol. 2014, 58, 511-518. [CrossRef]

35. Rodrigues, N.; Casal, S.; Peres, A.M.; Baptista, P.; Pereira, J.A. Seeking for sensory differentiated olive oils? The urge to preserve old autochthonous olive cultivars. Food Res. Int. 2020, 128, 108759. [CrossRef]

36. Monteleone, E. Sensory Methods for Optimizing and Adding Value to Extra Virgin Olive Oil. In Olive Oil Sensory Science; Monteleone, E., Langstaff, S., Eds.; Wiley-Blackwell: Hoboken, NJ, USA, 2014; pp. 109-140. ISBN 978-1-118-33252-8.

37. EU, E.C. Commision regulation (EU) no 2568791 of 11 July of 1991 and subsequent modifications on the characteristics of olive oil and olive-residue oil and on the relevant methods of analysis. Off. J. Eur. Union 1991, 248, 1-83.

38. Cantini, C.; Sani, G.; Gasperi, F.; Biasioli, F.; Aprea, E. Expert Panel Assessment of 57 Monocultivar Olive Oils Produced from the Tuscan Germplasm. The Open Agric. J. 2012, 6, 67-73. [CrossRef]

39. Bendini, A.; Valli, E.; Barbieri, S.; Toschi, T.G. Sensory Analysis of Virgin Olive Oil. In Olive Oil -Constituents, Quality, Health Properties and Bioconversions; IntechOpen: London, UK, 2012; Volume 6, pp. 109-130.

40. Bianchi, G.; Giansante, L.; Shaw, A.; Kell, D.B. Chemometric criteria for the characterisation of Italian Protected Denomination of Origin (DOP) olive oils from their metabolic profiles. Eur. J. Lipid Sci. Technol. 2001, 103, 141-150. [CrossRef]

41. Ben Ayed, R.; Rebai, A. Tunisian Table Olive Oil Traceability and Quality Using SNP Genotyping and Bioinformatics Tools. BioMed Res. Int. 2019, 1, 1-9. [CrossRef] [PubMed]

42. Ruiz-Samblás, C.; Cuadros-Rodríguez, L.; González-Casado, A.; Rodríguez-García, F.P. A straightforward quantification of triacylglycerols (and fatty acids) in monovarietal extra virgin olive oils by high-temperature GC. Anal. Methods 2012, 4, 753-758. [CrossRef]

43. Haddada, F.M.; Manaï, H.; Oueslati, I.; Daoud, D.; Sànchez, J.; Osorio, E.; Zarrouk, M. Fatty Acid, Triacylglycerol, and Phytosterol Composition in Six Tunisian Olive Varieties. J. Agric. Food Chem. 2007, 55, 10941-10946. [CrossRef] [PubMed]

44. Yorulmaz, A.; Yavuz, H.; Tekin, A. Characterization of Turkish Olive Oils by Triacylglycerol Structures and Sterol Profiles. J. Am. Oil Chem. Soc. 2014, 91, 2077-2090. [CrossRef]

45. Merckack, N.; Rizk, T.; Silvestre, V.; Remaud, G.S.; Bejjani, J.; Akoka, S. Olive oil characterization and classification by 13C NMR with a polarization transfer technique: A comparison with gas chromatography and 1H NMR. Food Chem. 2018, 245, 717-723. [CrossRef]

46. Peršurić, Ž.; Saftić, L.; Mašek, T.; Kraljević Pavelić, S. Comparison of triacylglycerol analysis by MALDI-TOF/MS, fatty acid analysis by GC-MS and non-selective analysis by NIRS in combination with chemometrics for determination of extra virgin olive oil geographical origin. A case study. LWT Food Sci. Technol. 2018, 95, 326-332. [CrossRef]

47. Bajoub, A.; Medina-Rodríguez, S.; Hurtado-Fernández, E.; Ajal, E.; Ouazzani, N.; Fernández-Gutiérrez, A.; Carrasco-Pancorbo, A. A first approach towards the development of geographical origin tracing models for North Moroccan olive oils based on triacylglycerols profiles. Eur. J. Lipid Sci. Technol. 2016, 118, 1223-1235. [CrossRef] 
48. Giuffrè, A.M. Influence of cultivar and harvest year on triglyceride composition of olive oils produced in Calabria (Southern Italy). Eur. J. Lipid Sci. Technol. 2013, 115, 928-934. [CrossRef]

49. Lukić, I.; Da Ros, A.; Guella, G.; Camin, F.; Masuero, D.; Mulinacci, N.; Vrhovsek, U.; Mattivi, F. Lipid Profiling and Stable Isotopic Data Analysis for Differentiation of Extra Virgin Olive Oils Based on Their Origin. Molecules 2019, 25, 4. [CrossRef]

50. Cerretani, L.; Bendini, A.; Caro, A.D.; Piga, A.; Vacca, V.; Caboni, M.F.; Gallina Toschi, T. Preliminary characterisation of virgin olive oils obtained from different cultivars in Sardinia. Eur. Food. Res. Technol. 2006, 222, 354-366. [CrossRef]

51. Baiano, A.; Gambacorta, G.; Terracone, C.; Previtali, M.A.; Lamacchia, C.; La Notte, E. Changes in phenolic content and antioxidant activity of Italian extra-virgin olive oils during storage. Food Chem. 2009, 74, 177-183. [CrossRef] [PubMed]

52. Ninfali, P.; Aluigi, G.; Bacchiocca, M.; Magnani, M. Antioxidant capacity of extra-virgin olive oils. J. Am. Oil Chem. Soc. 2001, 78, 243-247. [CrossRef]

53. Ricciutelli, M.; Marconi, S.; Boarelli, M.C.; Caprioli, G.; Sagratini, G.; Ballini, R.; Fiorini, D. Olive oil polyphenols: A quantitative method by high-performance-liquid-chromatography-diode-array detection for their determination and the assessment of the related health claim. J. Chromatogr. A 2017, 1481, 53-63. [CrossRef] [PubMed]

54. Olmo-García, L.; Fernández-Fernández, C.; Hidalgo, A.; Vílchez, P.; Fernández-Gutiérrez, A.; Marchal, R.; Carrasco-Pancorbo, A. Evaluating the reliability of specific and global methods to assess the phenolic content of virgin olive oil: Do they drive to equivalent results? J. Chromatogr. A 2019, 1585, 56-69. [CrossRef] [PubMed]

55. Di Vaio, C.; Nocerino, S.; Paduano, A.; Sacchi, R. Influence of some environmental factors ondrupe maturation and olive oil composition. J. Sci. Food Agric. 2012, 93, 1134-1139. [CrossRef]

56. Ripa, V.; De Rose, F.; Caravita, M.A.; Parise, M.R.; Perri, E.; Rosati, A.; Pandolfi, S.; Paoletti, A.; Pannelli, G.; Padula, G.; et al. Qualitative evaluation of olive oils from new olive selections and effects of genotype and environment on oil quality. Adv. Hort. Sci. 2008, 22, 95-103. [CrossRef]

57. Fiorini, D.; Boarelli, M.C.; Conti, P.; Alfei, B.; Caprioli, G.; Ricciutelli, M.; Pacetti, D. Chemical and sensory differences between high price and low price extra virgin olive oils. Food Res. Int. 2018, 105, 65-75. [CrossRef]

58. Brenes, M.; García, A.; García, P.; Garrido, A. Acid hydrolysis of secoiridoid aglycons during storage of virgin olive oil. J. Agric. Food Chem. 2001, 49, 5609-5614. [CrossRef] [PubMed]

59. Servili, M.; Baldioli, M.; Selvaggini, R.; Miniati, E.; Macchioni, A.; Montedoro, G. High-performance liquid chromatography evaluation of phenols in olive fruit, virgin olive oil, vegetation waters, and pomace and 1Dand 2D-nuclear magnetic resonance characterization. JAOCS 1999, 76, 873-882. [CrossRef]

60. Gambacorta, C.; Faccia, M.; Trani, A.; Lamacchia, C.; Gomes, T. Phenolic composition and antioxidant activity of Southern Italian monovarietal virgin olive oils. Eur. J. Lipid Sci. Technol. 2012, 114, 958-967. [CrossRef]

61. Robles-Almaza, M.; Pulido-Moran, M.; Moreno-Fernandez, J.; Ramirez-Tortosa, C.; Rodriguez-Garcia, C.; Quiles, J.L.; Ramirez-Tortosa, M.C. Hydroxytyrosol: Bioavailability, toxicity, and clinical applications. Food Res. Int. 2018, 105, 654-667. [CrossRef] [PubMed]

62. Carrasco-Pancorbo, A.; Cerretani, L.; Bendini, A.; Segura-Carretero, A.; Del Carlo, M.; Gallina-Toschi, T.; Lercker, G.; Compagnone, D.; Fernaä Ndez-Gutieä Rrez, A. Evaluation of the Antioxidant Capacity of Individual Phenolic Compounds in Virgin Olive Oil. J. Agric. Food Chem. 2005, 53, 8918-8925. [CrossRef] [PubMed]

63. Francisco, V.; Ruiz-Fernández, C.; Lahera, V.; Lago, F.; Pino, J.; Skaltsounis, L.; González-Gay, M.A.; Mobasheri, A.; Gómez, R.; Scotece, M.; et al. Natural Molecules for Healthy Lifestyles: Oleocanthal from Extra Virgin Olive Oil. J. Agric. Food Chem. 2019, 67, 3845-3853. [CrossRef]

64. Pang, K.; Chin, K. The biological activities of oleocanthal from a molecular perspective. Nutrients 2018, 10, 570. [CrossRef]

65. Bakhouche, A.; Lozano-Sanchez, J.; Beltran-Debon, R.; Joven, J.; Segura Carretero, A.; Fernandez-Gutierrez, A. Phenolic characterization and geographical classification of commercial Arbequina extra-virgin olive oils produced in southern Catalonia. Food Res. Int. 2013, 50, 401-408. [CrossRef]

66. Vidal, A.M.; Alcalá, S.; Ocaña, M.T.; De Torres, A.; Espínola, F.; Moya, M. Elaboration of extra-virgin olive oils rich in oleocanthal and oleacein: Pilot plant's proposal. Eur. Food Res. Technol. 2020, 246, 1459-1468. [CrossRef] 
67. Vidal, A.M.; Alcalá, S.; de Torres, A.; Moya, M.; Espínola, F. Industrial production of a balanced virgin olive oil. LWT 2018, 97, 588-596. [CrossRef]

68. Fuentes, E.; Paucar, F.; Tapia, F.; Ortiz, J.; Jimenez, P.; Romero, N. Effect of the composition of extra virgin olive oils on the di_erentiation and antioxidant capacities of twelve monovariatals. Food Chem. 2018, 243, 285-294. [CrossRef] [PubMed]

69. García-Martínez, O.; De Luna-Bertos, E.; Ramos-Torrecillas, J.; Ruiz, C.; Milia, E.; Lorenzo, M.L.; Jimenez, B.; Sánchez-Ortiz, A.; Rivas, A. Phenolic Compounds in Extra Virgin Olive Oil Stimulate Human Osteoblastic Cell Proliferation. PLoS ONE 2016, 11. [CrossRef] [PubMed]

70. Tuberoso, C.I.G.; Jerković, I.; Maldini, M.; Serreli, G. Phenolic Compounds, Antioxidant Activity, and Other Characteristics of Extra Virgin Olive Oils from Italian Autochthonous Varieties Tonda di Villacidro, Tonda di Cagliari, Semidana, and Bosana. J. Chem. 2016, 4, 1-16. [CrossRef]

71. EU, E.C. Commission regulation (EU) no 432/2012 of 16 May 2012 establishing a list of permitted health claims made on foods, other than those referring to the reduction of disease risk and to children's development and health. Off. J. Eur. Union 2012, 136, 1-40.

72. Bendini, A.; Cerretani, L.; Carrasco-Pancorbo, A.; Gómez-Caravaca, A.M.; Segura-Carretero, A.; Fernández-Gutiérrez, A.; Lercker, G. Phenolic molecules in virgin olive oils: A survey of their sensory properties, health effects, antioxidant activity and analytical methods. An overview of the last decade. Molecules 2007, 12, 1679-1719. [CrossRef]

(C) 2020 by the authors. Licensee MDPI, Basel, Switzerland. This article is an open access article distributed under the terms and conditions of the Creative Commons Attribution (CC BY) license (http://creativecommons.org/licenses/by/4.0/). 